\title{
Charting the course for a blue economy in Peru: a research agenda
}

\author{
Emma McKinley ${ }^{1}$ (D) Oscar Aller-Rojas ${ }^{3}$ - Caroline Hattam ${ }^{4} \cdot$ \\ Celine Germond-Duret ${ }^{5}$ - Inés Vicuña San Martín ${ }^{3,9}$ • Charlotte Rachael Hopkins ${ }^{6,8}$. \\ Héctor Aponte $^{3,7} \cdot$ Tavis Potts $^{2}$
}

\begin{abstract}
Ocean- and coastal-based economic activities are increasingly recognised as key drivers for supporting global economies. This move towards the "blue economy" is becoming globally widespread, with the recognition that if ocean-based activities are to be sustainable, they will need to move beyond solely extractive and exploitative endeavours,
\end{abstract}

Emma McKinley

mckinleye1@cardiff.ac.uk

Oscar Aller-Rojas

Oallerojas@gmail.com

Caroline Hattam

caro4@pml.ac.uk

Celine Germond-Duret

C.V.GermondDuret@ljmu.ac.uk

Inés Vicuña San Martín

inesv700@gmail.com

Charlotte Rachael Hopkins

hopkins.charlotte1@gmail.com

Héctor Aponte

hectoaponte@gmail.com

Tavis Potts

tavis.potts@abdn.ac.uk

1 Cardiff University, Cardiff, UK

2 University of Aberdeen, Aberdeen, UK

3 Carrera de Biología Marina, Universidad Científica del Sur, Lima, Peru

4 Plymouth Marine Laboratory, Plymouth, UK

5 Liverpool John Moores University, Liverpool, UK

6 University of Glasgow, Glasgow, UK

7 Laboratorio de Florística, Museo de Historia Natural UNMSM, Lima, Peru

8 University of Liverpool, Liverpool, UK 
aligning more closely with marine conservation and effective marine spatial planning. In this paper we define the "blue economy" as a "platform for strategic, integrated and participatory coastal and ocean development and protection that incorporates a low carbon economy, the ecosystem approach and human well-being through advancing regional industries, services and activities". In Peru, while the seas contribute greatly to the national economy, the full potential of the blue economy has yet to be realised. This paper presents the findings of an early career scientist workshop in Lima, Peru, in March 2016. The workshop "Advancing Green Growth in Peru" brought together researchers to identify challenges and opportunities for green growth across three Peruvian economic sectors-tourism, transport and the blue economy with this paper exploring in detail the priorities generated from the "blue economy" stream. These priorities include themes such as marine spatial planning, detailed evaluations of existing maritime industries (e.g. guano collection and fisheries), development of an effective MPA network, support for sustainable coastal tourism, and better inclusion of social science disciplines in understanding societal and political support for a Peruvian blue economy. In addition, the paper discusses the research requirements associated with these priorities. While not a comprehensive list, these priorities provide a starting point for future dialogue on a co-ordinated scientific platform supporting the blue growth agenda in Peru, and in other regions working towards a successful "blue economy".

Keywords Blue growth $\cdot$ Blue economy $\cdot$ Marine $\cdot$ Society $\cdot$ Sustainability

\section{Introduction: the blue economy and Peru}

Ocean- and coastal-based economic activities and their associated growth potential are seen as an important driver for bolstering economies around the world. Some countries are beginning to actively support the opportunities associated with this blue growth through policy initiatives (e.g. EU Blue Growth Strategy; the Sustainable Development Strategy for Seas of East Asia; Seychelles Blue Economy Strategic Roadmap). These strategies recognise that if ocean-based economic activities are to be sustainable, they need to move beyond resource exploitation and integrate with marine conservation and effective marine planning; this has led to the development of the "Blue Economy" concept.

\subsection{The advancing green growth in Peru workshop}

The Advancing Green Growth in Peru workshop was co-organised by the University of Aberdeen, the Universidad Cientifica Del Sur and the Pontifical Catholic University of Peru, and funded by the British Embassy, Lima, and the British Council Researcher Links program. The workshop, held in Lima in March 2016, occurred over five days and was attended by 44 researchers from 22 Higher Education and policy institutions.

The aim of the workshop was to explore the challenges and obstacles inhibiting sustainable growth in tourism, transport and the blue economy; considering social, political, economic and technical pathways that boost green growth and collaborate to produce a co-ordinated research agenda that advances the green economy in Peru. 
The objectives of the workshop were to:

- Develop an overview of the status of the three sectors (tourism; transport; "blue economy") within a green growth context. Achieved by identifying existing data, knowledge exchange and dialogue in collaboration with Peruvian partners.

- Explore challenges and obstacles inhibiting sustainable growth in the 3 sectors.

- Consider social, political, economic and technical pathways that boost green growth in the identified sectors that is considered socially just.

- Collaborate to produce a co-ordinated research agenda that advances the green economy in Peru, promotes green jobs and increases opportunities for international exchange, dialogue and co-operation.

The first part of the workshop brought together early career researchers to make initial connections, identify interests and discuss the issues facing transportation, tourism and marine industries in the context of Peru. These sessions were transdisciplinary and cross-sector, enabling a rich exchange of ideas. Furthermore, project mentors from the UK and Peru (senior scientific and policy representatives) presented global drivers and trends within in tourism, transport and the blue economy and the dynamics and challenges of local, regional and national (Peruvian) issues. The second part of the workshop involved the themed groups (i.e. blue economy) identifying research priorities and feeding this back for plenary discussion and dialogue with industry and policy stakeholders in the context of industry trends and political realities. This included the Ministry of the Environment, PAGE (Partnerships for Action on the Green Economy), National Council of Science and Technology, the Technology Innovation Centres and representatives from the tourism, transport and seafood sectors. The third day of the workshop consisted of a field visit to sites of green economy importance in the broader Lima region including visits to the main Lima city fish market, a visit to Pachacamac to identify tourism pressures and visits to sites of transport and urban planning significance.

\subsection{Development of the blue economy concept}

The term "blue economy" emerged from the preparatory process for the Rio +20 United Nations Conference on Sustainable Development in 2012 (Anon 2014). Rio + 20 underwent a distinct economic turn from the concept of sustainable development towards the notion of the "green economy", defined as an economy that results in "improved human well-being and social equity, while significantly reducing environmental risks and ecological scarcities", endorsing principles of low carbon, resource efficiency and social inclusion (UNEP 2011, p. 3). The green economy concept centralised neoliberal economic concerns within the sustainability discourse, including the expansion of "green jobs", market-based instruments and public-private partnerships. The concept emerged in parallel with and was influenced by the financial crisis in 2008. The green economy was billed as a potential route out of the crisis for developed and developing States, a means to restart economic growth through ecological modernisation. Small Island Developing States (SIDS) and other coastal nations questioned the "green economy" emphasis during the run up to Rio +20 and its applicability to them, given their dependence upon the ocean. SIDS proposed the "Blue Economy", a definition for ocean-based economies that encompasses conservation, sustainable use, oil and mineral wealth extraction, bio-prospecting, sustainable energy production and marine transport, all integrated through marine planning (Anon 


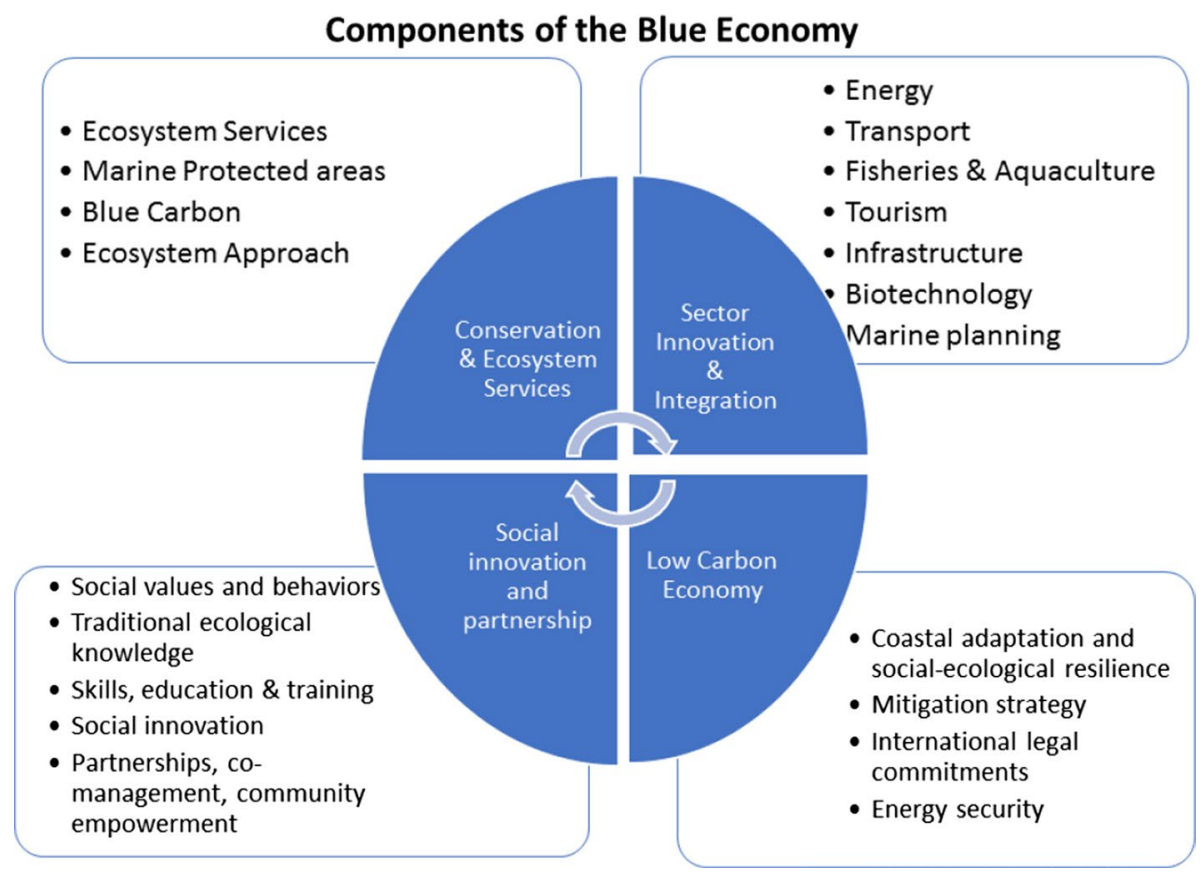

Fig. 1 Model components of the blue economy (Reproduced with permission from Potts 2016)

2014). However, there was no agreed definition of "Blue Economy" and the term has subsequently been used in multiple and competing ways (Silver et al. 2015). Examples of this include:

- Green Economy in a blue world (UNEP, FAO, IMO, UNDP, IUCN, World Fish Center, GRID (UNEP 2012), where the ideals of the green economy are transposed into the ocean environment.

- Green growth integrating fisheries, aquaculture and environment (OECD 2015) where prominence is given to applying green economy principles to fisheries and aquaculture.

- Blue growth (FAO 2013) emphasising "conservation and sustainable management, based on the premise that healthy ocean ecosystems are more productive and critical for sustainable ocean-based economies", implemented through aquaculture, capture fishery, seafood systems and ecosystem services.

- Blue growth (European Commission 2012) viewed as an opportunity for marine and maritime sustainable growth and a new and innovative way to help the European Union emerge from its current economic crisis.

The blue economy is an integrative concept (as presented in Fig. 1), subject to reframing and debate over its meaning. One perspective refers simply to the growth of traditional and new maritime industries and the integration of sectors through processes such as marine spatial planning (MSP). What is novel within the concept, and subject to considerable debate, is the extent to which ecological and climate concerns influence the trajectory of the blue economy. Recent policy outputs such as "Africa's Blue Economy" (United Nations Economic Commission for Africa 2016) promote an interconnected view of the blue economy, 
highlighting a holistic approach to sector development with an emphasis on low carbon industries, and healthy marine systems underpinned by social inclusion and participation. For the purposes of this paper, we define the blue economy as a "platform for strategic, integrated and participatory coastal and ocean development and protection that incorporates a low carbon economy, the ecosystem approach and human well-being through advancing regional industries, services and activities" (Potts 2016).

\subsection{Peru's coast and sea, and the blue economy}

In Peru, and Latin America generally, while the ocean makes a substantial contribution to GDP, the full potential for the blue economy has yet to be recognised. The Peruvian coastline stretches over $3000 \mathrm{~km}$ from Ecuador in the north to Chile in the south, encompassing diverse ecosystems including: coastal wetlands, bays and hundreds of islands and capes. Coastal wetlands consisting of mangroves, lakes, marshes, lagoons and river mouths are vital for the conservation of coastal biodiversity and ecosystem services (Aponte and Cano 2013). Peru has designated 13 sites as Wetlands of International Importance (RAMSAR), including five coastal sites: Santuario Nacional Los Manglares de Tumbes, Manglares de San Pedro de Vice, Zona Reservada Los Pantanos de Villa, Paracas, and Santuario Nacional Lagunas de Mejía. The Exclusive Economic Zone (EEZ) of Peru, covers an area of 906,454 km² incorporating diverse marine ecosystems from tropical coral reefs to the cold Humboldt Current large marine ecosystem. Management of these marine and coastal resources will be fundamental to the development of any Peruvian Blue Economy Strategy. Although policies for the sustainable use of marine resources have been developed, including the General Fisheries Law (Decree Law N ${ }^{\circ}$ 25977, published in 1992), the OECD Territorial Report (2016) questions the effectiveness of this, and other regional policies. The Report also suggests improvements are required within Peruvian environmental and economic policies to ensure there is sustainable framework to promote diversification, regulate fisheries, support sustainable development and ensure the responsible use of aquatic resources. Additional management is present where natural resources, such as hydrocarbons (oil, gas) and fertilisers (guano), are extracted from the Peruvian waters and islands, which are regulated by decree laws established by their respective ministries, regulating and insuring its sustainable extraction.

In view of the high biodiversity and productivity of Peru's marine environment (Bakun and Weeks 2008; Tarazona et al. 2003), this sector has the potential to underpin the growth of a successful and diverse blue economy. Maritime industries are an important contributor to the Peruvian economy, with key industries (fishing, oil and gas, tourism and guano) generating thousands of jobs. The fisheries sector alone generates more than 200 thousand jobs (Christensen et al. 2014) and was estimated to be worth \$3.2 billion in 2009 (Christensen et al. 2014). Peru has the opportunity to use the blue economy concept to provide a framework for protection and sustainable use of the richly biodiverse marine and coastal environment to develop a diverse, sustainable and low carbon marine economy. To support the development of this blue economy, this paper presents the findings from the blue economy theme of the workshop "Advancing Green Growth in Peru; A Spotlight on Tourism, Transport and the Blue Economy" in March 2016. 


\section{Identifying priority areas for a blue economy in Peru}

Priority research areas were identified during the workshop, guided by the policy context and according to the interests of the researchers present. All ideas for research in support of the blue economy were initially collated, resulting from group discussions, researcher presentations and policy input (e.g. the Ministry of the Environment). During the final day, these ideas were further refined and reduced to avoid overlap and repetition. A final list of nine was presented to all workshop members. This paper presents a brief review of the status of knowledge for each priority area together with gaps in knowledge that could be filled with future research activities. While the list is not exhaustive and reflects the in part the disciplinary backgrounds of the workshop participants, this paper provides a starting point for researchers, practitioners and policy makers seeking to raise the profile of the blue economy and its associated marine sectors in Peru, as well as a research agenda for co-operation and development.

\subsection{Marine protected areas and ecosystem services}

Compared to terrestrial ecosystems, scientific research and conservation of the marine ecosystems in Peru has been limited (Tarazona et al. 2003). The slow establishment of Marine Protected Areas (MPAs) is a pressing concern (Hooker 2011), particularly if Peru is to meet SDG Goal 14. Increasing the speed of MPA establishment is urgently required to mitigate pressure on the marine environment in Peru including: illegal fishing and overexploitation, pollution, invasive species, growing industry and population along the coast and the impacts of El Niño and climate change (Bakun and Weeks 2008; SERNANP 2009; FAO 2012; ECLAC and OECD 2016). Peru is a signatory of several international agreements which include obligations to protect marine ecosystems and migratory species. For example, Peru is a partial signatory to Convention of Biological Diversity 2011-2020 (Ipenza Peralta 2010) and is a full signatory to the Transforming our World: 2030 Agenda for Sustainable Development. This gives Peru a target of conserving at least $10 \%$ of the marine environment in an ecologically representative MPA network (through Sustainable Development Goal (SDG) 14). In Peruvian legislation, the Law on Conservation and Sustainable Use of the Biological diversity (26839) gives effect to the provisions of the CBD while Peru's National Environmental Policy (Ministerio del Ambiente 2009) on sustainable development and environmental management provides the base for protecting biological diversity. Furthermore, the Multisectoral Commission for Environmental Management of the Coastal Marine Environment (COMUMA), established in 2012 to co-ordinate administrative and technical agencies involved in protection of the sea, could be an effective tool for designing integrated policy on the protection and sustainable management of the marine environment (ECLAC and OECD 2016).

MPAs in Peru are included in the National System of Protected Natural Areas (SINANPE), administrated by the National Service of Protected Areas by the State (SERNANP) under the Ministry of Environment (MINAM). MPAs are currently only designated under national policy, primarily through National Reserves (Reservas Nacionales). Marine and coastal areas are currently underrepresented in the protected area system with only three MPAs legally designated covering $4039 \mathrm{~km}^{2}$, or $0.4 \%$ of Peru's EEZ (MINAM 2016). Paracas National Reserve (a subtropical coastal desert which is also a RAMSAR site), San Fernando National Reserve, and the National Reserve System of Guano Islands, Isles, and 
Capes. Recently, the Ministry of Environment (MINAM) and SERNANP proposed "Zona Reservada Mar Pacifico Tropical" along the coastal regions of Piura and Tumbes, which would add an additional $1160 \mathrm{~km}^{2}$ of marine protection and cover a biodiversity hotspot, home to more than $70 \%$ of Peru's marine species. Presently, the area is lacking in protection and a combination of artisanal and illegal fishing, unregulated tourism and waste disposal at sea have prompted the Peruvian Government to prioritise conservation in this area through the designation of an MPA (MINAM 2016). Supporting reasons for the MPA have included protecting biodiversity for the provision of fish stocks (an important protein source for northern Peru); developing the tourism potential of the area; and contributing towards tackling climate change and meeting the target of protecting $10 \%$ of marine areas (MINAM 2016).

Peruvian seas' high biodiversity underpins a range of Ecosystem Services (ES) of significant economic and social value (Sevilla and Le Bail 2017) including provision of food and seaweed (Rebours et al. 2014); climate regulation and coastal protection (Sevilla and Le Bail 2017); cultural services including coastal tourism (Guezel and Wickel 2015) and primary production and nutrient cycling (Bakun and Weeks 2008). The expansion of the MPA network will contribute to the continued delivery and enhancement of these services: a well-designed MPA could support local fisheries; increase spatial protection of charismatic species leading to opportunities for ecotourism; and support the resilience of coastal communities by protecting habitats important for climate regulation and supporting services. The current MPA network and any future sites would need to be effectively managed.

MPAs are an important tool in the protection of marine biodiversity and will, by necessity, form a key component of a vision for a sustainable blue economy for Peru. Workshop participants identified a number of areas of research that would underpin the development of an effective MPA network, and in particular, proposed the use of an ES framework to guide research priorities. As a mechanism for describing the link between ecosystems and human well-being, an ES framework would provide a more holistic perspective of socioecological systems, assisting in better understanding and managing the benefits that people derive from Peru's marine ecosystems. Peru's highly productive marine environment generates an array of ES whose ecological, economic and social value is only now beginning to be recognised (World Bank 2006). In particular, anchoveta (Engraulis ringens) and small pelagic stocks are a food source supporting marine birds and mammals which in turn support a growing marine ecotourism industry in the Pisco-Paracas area, valued at some US\$7-9 million/year (World Bank 2006). An ES framework would provide an effective methodology for the evaluation of these ecosystem benefit flows. While there have been demonstrable benefits of MPA designation to provisioning services, e.g. guano production (IUCN 2013), other ES such as climate regulation and nutrient cycling have not been explicitly considered in the MPA network. Data gaps for evaluating the MPA network include what services are provided by what ecological biomes, how does MPA designation impact these services and their values, and what contribution do MPAs make to the wellbeing of communities dependent upon these areas. An ES framework could highlight gaps in protection for the delivery of ES within the Peruvian MPA network and identify areas where protection, through new designations, may be increased. Threats to the delivery of services within specific sites would also be identified, informing management responses both at an MPA site level and at a wider seas planning level. An evaluation of the multiple benefits and services, and any potential burdens, provided/resulting from the Peruvian MPAs, could play a central role in good governance and long-term security of a healthy marine environment. 
The lack of baseline data on marine and coastal ES is seen as a major obstacle to implementing effective MPA policy (Potts et al. 2014). The Peruvian marine environment is a region where the socio-economic value and importance of fishery resources is recognised as high, but consideration of other ES is relatively under-researched. Using an ES framework to evaluate MPA effectiveness will therefore address the balance between ES within the decision-making process (Cavanagh et al. 2016). Integration of ES assessments of MPAs with other research priorities was identified as an important consideration, particularly in relation to the role of MPAs within marine spatial planning and the contribution of MPAs to other economic activities, e.g. coastal tourism and blue carbon.

\subsection{Blue carbon: habitat protection, ecosystem services and carbon markets}

Blue carbon is the carbon stored in coastal and marine ecosystems, including mangroves, tidal marshes and seagrass (Nellemann et al. 2009). The ability of these ecosystems to sequester and lock away carbon assists in the mitigation of climate change and is a critical and untapped service (Palomino Contreras and Cabrera Carranza 2007). Despite the multitude of ecosystem services that flow from these ecosystems (Potts et al. 2014), they are under substantial threat from over development, pollution and climate change impacts with an estimated $340-980 \mathrm{~km}^{2}$ destroyed by coastal development every year (Howard et al. 2014). While the value and distribution of this ES is poorly understood, carbon sequestration is increasingly an important policy issue and an opportunity for coastal communities to mitigate and adapt to climate impacts (Luisetti et al. 2013).

Investment in blue carbon has the potential to leverage economic support for the conservation and restoration of coastal ecosystems (Pendleton et al. 2012; Grimsditch et al. 2013). By entering blue carbon projects into schemes such as the UNFCCC Reducing Emissions from Deforestation and forest Degradation (REDD+), they can steer economic resources to communities via the transfer of carbon credits while simultaneously encouraging ecosystem protection. To date, such efforts to integrate blue carbon into international emissions reduction mechanisms are predominantly theoretical and limited experience exists in practical implementation of schemes particularly around accounting and verification of emissions reductions from coastal habitats. Recent attention, however, has shifted to the potential for inclusion of mangroves and seagrasses in REDD + (Ahmed and Glaser 2016; Alongi et al. 2016). The Peruvian coastline is rich in wetlands and mangrove forests with more than 90 recognised coastal wetlands (Leon and Young 1996; Pronaturaleza 2010). If these are to be included in emissions reduction schemes such as REDD+, there is a need to further knowledge on the extent, quality and condition of blue carbon biomass and its rate of sequestration. This will advance understanding about how much carbon is stored in these habitats and support their adequate management. Peru has developed mechanisms to protect these ecosystem services, including Mechanisms of Clean Development (Mecanismos de Desarrollo Limpio) and REDD + mechanism, but they are currently not applied to coastal ecosystems. The Peruvian Council for Science Technology and Research (CONCYTEC) is therefore promoting research on this topic.

Workshop participants proposed that Blue Carbon Capture could be a designation criterion for new MPA sites, incorporating ES into MPA selection in addition to the protection of biodiversity. However, to do this would necessitate adequately mapping and effectively quantifying the level of carbon that is sequestered and stored within Peruvian coastal ecosystems and the economic value of that carbon for the purpose of carbon accounting and management. This information will support the assessment of Peru's coastal systems, 
linking national pledges and carbon strategies to the global carbon market. While it is premature to establish blue carbon markets in Peru, it represents a significant opportunity to reduce coastal habitat destruction and contribute to the Peruvian Nationally Determined Contribution under the UNFCCC Paris climate agreement.

\subsection{Evolving Peruvian fisheries}

Peruvian fisheries are characterised by both their economic diversity (industrialised to subsistence) and by their natural variability (maritime to Amazonian), with the highly productive Peruvian sea favouring the development of industrial scale maritime fisheries targeting pelagic species (FAO 2010; ECLAC and OECD 2016). Industrial anchoveta fisheries account for $86 \%$ of catch enabling Peru to be the world's leading producer of fishmeal and fish oil (Young and Lankester 2013; ECLAC and OECD 2016), while the multi-species artisanal fishery is primarily for human consumption. Fish are invaluable to Peruvian food security, equating to $20 \%$ of total protein intake (FAO 2016), and fish consumption per capita is high at 20-30 kg/person/year (FAO 2016), positioning Peru in the category of third highest fish-consuming countries. The fisheries themselves support over 232,000 jobs (Christensen et al. 2014) and contribute approximately $0.4 \%^{1}$ to national GDP, increasing to $0.8-1.4 \%$ when including processing value (BCRP 2016). The exact combined contribution of fisheries and associated industries to the Peruvian economy is largely unknown. The vast number of species (approximately 300) fished by industrial and artisanal fleets in Peruvian waters, include fish, molluscs, bivalves and algae (FAO 2010), the different products derived from them and the large number of people that depend economically (both formally and informally) on these fisheries, makes it hard to estimate a precise value. Christensen et al. (2014), however, estimate an economic multiplier effect from the Peruvian fishing industry of 2.9 on average irrespective of fleet and seafood category. Employment multipliers were similar in magnitude.

The Ministry of Production (PRODUCE) is responsible for fisheries management, supported by biological (species distribution and biomass) and fishery (effort and landing) data provided by the Peruvian Marine Institute (IMARPE). PRODUCE has applied different fisheries management tools aimed at supporting sustainability across Peruvian fisheries, including: the implementation of the Individual Vessel Quota (IVQ) programme for industrial anchoveta fishery vessels in 2009 (Young and Lankester 2013); the ROP (Reglamento de Ordenamiento Pesquero) fisheries regulations, applied to specific species for both the industrial or artisanal fleet; and minimum catch sizes and temporal extractive closures regulations. However, despite recent improvements to inter-agency co-operation on marine issues, Peruvian fisheries policy still has a sectoral approach rather than an ecosystem approach, resulting in no comprehensive plan for the anchovy fishery (ECLAC and OECD 2016). Issues remain in the anchovy fishery that continue to undermine sustainability including: overcapacity and economic inefficiency, negative environmental and ecosystem impacts, weak governance, a deficient environmental oversight and regulatory framework; inadequate institutional arrangements and role of civil society; and the unrealised contribution to Peruvian society (World Bank 2006).

Traceability of products within Peru's artisanal fisheries and the level of fishing activity are difficult to account for, resulting in a significant undervaluing of an important market. Workshop delegates proposed an in-depth evaluation of Peruvian fisheries, across supply

\footnotetext{
${ }^{1}$ Figure based on extraction value alone, excluding any added value that may come through processing or movement through the supply chain.
} 
chains within both industrial and artisanal fisheries, to identify its contribution to both the blue economy and the Peruvian economy as a whole. Development of predictive and exploratory scenarios could also be used to investigate the impact of changes in fishing practices on fish stocks, impacts on the individual fleets and the wider fishery sector, as well as impacts on the communities dependent on the industry. Finally, it is recommended that research focusing on the public perceptions of fisheries in Peru, and the implications of campaigns to change human consumption of anchovy, is required to ensure the implementation of actions to support a sustainable fishing industry (discussed further in Sect. 2.5).

\subsection{Opportunities for coastal ecotourism}

Tourism is the third largest industry in Peru, contributing 9\% to GDP (World Travel and Tourism Council 2015), with over 3 million international visitors in 2014 (World Bank n.d.). A large proportion of international tourists visit Peru for its cultural heritage, especially the Cuzco region (Machu Picchu), and more recently, Peru has benefited from global interest in ecotourism, adventure travel and nature-based activities. Peru experiences high levels of polarisation of tourism activity, with activities concentrated in the Cuzco region (Llorca-Rodríguez et al. 2014). Coastal and marine ecotourism has the potential to offer alternative destinations, while at the same time contributing to Peru's blue economy.

Ecotourism is a contested term but the generally accepted definition is "environmentally responsible travel and visitation to relatively undisturbed natural areas, in order to enjoy, study and appreciate nature (and accompanying cultural features), that promotes conservation, has low negative visitor impact, and provides for beneficially active socio-economic involvement of local populations" (Ceballos-Lascurain 1993). Ecotourism encompasses different types of activities, from "deep ecotourism" to "shallow ecotourism" (Acott et al. 1998) and should not be confused with sustainable tourism. Sustainable tourism aims at a balance between the environmental, economic and sociocultural dimension (Mowforth and Munt 2009). Most research has focused on how to minimise negative impacts of tourism rather than how it could contribute to the sustainable development of a given destination (Creaney and Niewiadomski 2016).

MPAs and Peru's diverse coastal ecosystems all represent potential for nature-based ecotourism. Marine ecotourism activities are already taking place in Paracas, including tours to the Ballesta Islands to observe seabirds and sea lions (Donlan et al. 2014). Although studies on coastal tourism and ecotourism in Peru are limited, workshop delegates identified this as a clear opportunity for developing a new tourism offer within Peru, supporting coastal areas while potentially reducing pressures on traditional destinations. If the sector is to grow in the context of the blue economy, several issues must be considered, including the impact of increased human interactions with the Peruvian coast. Existing protected areas, which could be a focal point for the development coastal ecotourism, are already experiencing negative impacts from an increase in tourism; for example, Paracas Bay is affected by human activities, from water-sports to fishing and aquaculture (Guezel and Wickel 2015), while urban development along the coast (including hotels, housing, marinas, and wastewater discharge) is an ecological risk (e.g. contaminated water). The Mangroves of San Pedro de Vice in the northern part of Peru have also experienced increased pressure due to inadequate management and lack of planning, while litter left by tourists accumulates and impacts wildlife (RAMSAR 2008).

To date, little research has been conducted on the relationship between tourism and conservation in Peru and the integration between economic and environmental needs (Bury 
2008). Coastal ecotourism represents an opportunity to diversify tourism, contributing to any future blue economy goals developed by Peru, as well as supporting the national economy. Research to map coastal ecosystems (opportunities and vulnerabilities) as well as socio-economic contexts (livelihoods, culture and values, stakeholders) is necessary to understand the dynamics involved in any ecotourism development, predicting and preventing any conflict that could arise. Environmental impact monitoring and mitigation research would also be required, including determining who has responsibility for such actions. The social acceptability of any planned local developments resulting from coastal ecotourism would also be a research priority, as well as identifying impacts on local communities, and the mechanisms through which local communities can be part of, or even drive, and benefit from this process. Privatisation of tourism will also have to be addressed, as the involvement of national and international tour companies increases the risk of green and blue grabbing (the appropriation and neoliberalisation of nature by ecotourism and naturebased activities (Fairhead et al. 2012; Duffy 2015; Silver et al. 2015). In this respect, the mechanisms necessary to manage coastal tourism efficiently and sustainably need to be investigated (public policies, legal framework). Most importantly, research on the feasibility and desirability of coastal ecotourism principles and indicators would be necessary to garner political and public backing to successfully grow the sector.

\subsection{Sustainable regeneration of the guano industry}

The traditional guano industry remains active on the Peruvian guano islands and coastlines owing to the highly productive marine system supported by the Humboldt Current. The network of small islands, offshore sea stacks and coastal headlands provides optimum nesting grounds for guano-producing seabird populations (Duffy 1994; Crawford and Jahncke 1999; Jahncke et al. 2004; IUCN 2013). Historically, Peru has been the largest guano producer globally, supplying demand for agricultural fertiliser (IUCN 2013). Overexploitation of Peru's guano islands in the early twentieth century resulted in the near collapse of the industry due to the reductions in the populations of Peruvian guano-producing seabirds: Guannay Cormorant, Phalacrocorax bougainvilli; Peruvian Booby, Sula variegata and the Peruvian Brown Pelican, Pelecanus occidentalis (Duffy 1994; Jahncke et al. 2004; IUCN 2013). In a bid to protect seabirds and revitalise a valuable industry, government interventions improved management in the early twentieth century (IUCN 2013; Duffy 1994). While these interventions were initially successful (e.g. restricting access to guano bird nesting areas), industrialisation and overfishing of the seabirds' main food source, the Peruvian anchoveta, coupled with a reduction in primary productivity, led to limited recovery of seabird populations, and therefore, of the guano industry (Duffy 1994; Jahncke et al. 2004; Hannesson 2013). Events such as El Niño 1997-1998 also affected populations of guano birds such as Pelacanus thagus, Phalacocorax bouganvillii, Sheniscus humboldtii and Sula variegata in some regions of Peru; this was due to the absence of the anchovy during that period, which was closely correlated with changes in sea temperature (Apaza and Figari 1999). The biodiversity and social history value of the guano islands has since been recognised and in 2009, the Guano Islands and Capes National Reserve System was established as the first MPA network in South America (IUCN 2013). This designation has ensured protection of the guano islands, and the associated biodiversity of the Humboldt Current, while also supporting sustainable extraction of guano resources.

From a blue economy perspective, workshop participants identified two potential growth opportunities and areas for research associated with the guano islands and their 
seabird populations; firstly, growth of a sustainable market for guano-derived fertiliser and secondly eco- or nature-based tourism and recreation activities linked to the guano islands as designated protected sites. To achieve the first, given national and global interest in organic, natural fertilisers for gardening and agriculture sustainable rates of harvesting the resource should be established. This would need to be coupled with improved regulation of guano harvests, co-ordination and co-operation with the fishing industry to ensure the availability of the seabird food supply, and expansion of the existing Peruvian MPA network, to ensure regulation of other activities that might impact guano-producing seabird colonies.

Achieving the second could be linked to the promotion of the guano islands as part of an MPA network. Protected area designations have been shown to be significant tourist attractions (Chae et al. 2012; Woodland and Acott 2007). This, coupled with promotion of the cultural and historical importance of the islands, could support the development of a strong coastal tourism sector (as discussed in Sect. 2.6). Research would need to identify the potential environmental, social and economic impacts of any tourism development, potentially identifying a tourist carrying capacity for the islands to reduce seabird disturbance. Mechanisms for ensuring the benefits accrue to coastal communities would also need investigating.

While there are clearly blue growth opportunities associated with the guano islands of Peru, if these are to be successfully and sustainably developed, a co-ordinated and system approach to managing the supporting ecosystems will be required. Peru will need to develop an understanding of small scale activities, such as the guano industry, across a number of sectors; spatially mapping human activities, what the impacts are and how these affect the guano islands. Any efforts to develop either a sustainable guano industry or an ecotourism industry linked to the protected area designations will therefore require co-ordination with the anchoveta fishery and the MPA network.

\subsection{Marine spatial planning in Peru}

Defined as a "public process of analysing and allocating the spatial and temporal distribution of human activities in marine areas to achieve ecological, economic and social objectives" (IOC-UNESCO 2018), marine spatial planning (MSP) is recognised as a tool through which to deliver integrated sector planning within the blue economy in attempt to reduce conflict and pressure on natural resources (Douvere 2008; Ehler 2008; Maes 2008; Pomeroy and Douvere 2008; Maguire et al. 2011). Marine plans provide policy makers, industry stakeholders and communities with the opportunity to form a common vision for their seas (Agardy et al. 2011). While a Peruvian marine spatial plan is still to be developed, there is evidence to suggest that this would be a welcome addition to the current national marine governance landscape, with a recent call for tenders to initiate MSP launched in 2015 (DEVEX 2015). The development of an up to date marine spatial plan would ensure recognition of existing sectors currently operating within the Peruvian coastal and marine area, identifying areas of conflict, choke points between sectors, and areas of blue growth. Carefully developed marine spatial plans in Peru should also support conservation goals, integrating Marine Protected Area (MPA) designations with sector activities and linking vulnerable marine and coastal ecosystems to support ecological connectivity (Agardy et al. 2011).

For a Peruvian Marine Spatial Plan to be effective, a number of research priorities must be addressed. A first step would be to accurately map all drivers, uses and pressures on the 
Peruvian coastline allowing planners to assess choke points and sites of potential conflict. Research efforts should focus on effective community participation and social learning throughout the plan development. Local communities have a valuable contribution to make to MSP processes, with many studies indicating early engagement results in the development of effective plans and successful implementation (Maguire et al. 2011; Gopnik et al. 2012). Research will be needed to assess how future marine plans can support integration and complementarity with terrestrial planning (Smith et al. 2011; Turner and Essex 2016). Additionally, a successful Peruvian marine plan will require effective governance mechanisms and institutional frameworks to implement plans and support monitoring, evaluation and enforcement to ensure they are achieving desired goals.

\subsection{Marine renewables}

Climate change has driven global efforts to move away from fossil fuel dependency with consequent investment in renewable energy (Pelc and Fujita 2002; Wüstenhagen et al. 2007; Copping et al. 2014; Leeney et al. 2014; Borthwick 2016). As a middle income nation, Peru is experiencing increasing energy demand. Historically, the country's energy supply has been dominated by fossil fuels (López et al. 2015) with dependency on oil imports to meet the nation's energy demand (Apergis and Payne 2010). Energy security (i.e. continued supply) and social access to energy particularly from marginalised groups is a pressing concern. In response, Peru is making efforts to move towards renewable energy sources; in 2014, the Minister of Energy and Mines announced plans for renewable energy to meet $66 \%$ of Peruvian energy demand by 2024 (REVE 2016) while the Law to Promote Electricity Generation with Renewable Resources of 2008 highlighted renewable energy production as a national priority (Norton Rose Fulbright 2016). Currently, renewable energy activity in Peru is dominated by hydroelectric, onshore wind and solar energy (López et al. 2015; REVE 2016). Although the potential for ocean energy in Peru is currently unknown (Norton Rose Fulbright 2017), its coastal location and position on the edge of the South American continent, lends itself to growth of a marine renewable energy (MRE) sector. Potential MRE sources that could be exploited include offshore wind, wave, tide, thermal gradients, ocean currents, biomass and salinity gradients (Leeney et al. 2014; Borthwick 2016). A wave energy demonstration project is underway in Ilo, southern Peru, although the cheap energy market in Peru means that the cost of wave energy production makes is currently economically unviable (Tidal Energy Today 2015). In comparison with other Latin American countries, there has been relatively slow development of the renewable energy sector in Peru (Apergis and Payne 2010). However, at a time of volatile oil and gas prices, and general economic flux, investment in the marine renewable energy sector could provide Peru with an early mover advantage, support energy distribution and decentralisation and support other blue economy initiatives.

Global challenges to the successful commercialisation of MRE remain associated with technology developments, infrastructure and supply chain readiness, high capital investment requirements, energy cost reduction needs, uncertainty about environmental impacts, social acceptability, marine governance, licensing and related legislation (Wüstenhagen et al. 2007; Kerr et al. 2014; Borthwick 2016). Each of these challenges supports opportunities for research across a range of sectors in Peru; relating to skills and training development, growth in direct and indirect employment associated with the installations (Kerr et al. 2014), the potential for improved marine planning and governance in Peru and greater energy security. 
Workshop delegates recognised that not all MRE options may be suitable for installation in Peru; for example, the narrow Peruvian continental shelf poses challenges to the deployment of fixed foundation offshore wind. However, in terms of wave and tidal energy, López et al. (2015) estimated the Peruvian wave energy resource as being moderate to high (300TW h/year, i.e. seven times the total annual energy consumption of Peru based on a per capita consumption of $1300 \mathrm{kWh}$ ). Additionally, given the predictability of tidal energy, Peru could also look to combined MRE arrays (i.e. wave and tidal energy). In a country with growing energy needs, there may also be the possibility for community renewable energy initiatives (Walker and Devine-Wright 2008) to be developed in coastal communities, although cost may currently be prohibitive. Initially, research efforts would be concentrated within the engineering and design sector, including feasibility studies to examine potential MRE opportunities, the consistency of the resource and deployment options. Research would be required to evaluate infrastructure, energy storage, national grid connection and the value of this sector to the national economy. Growth of the MRE market in Peru could lead to studies investigating community renewables as a way of improving energy access and security and detailed understanding of the environmental impacts of MRE installations (Copping et al. 2014). In addition, it will be important to understand public perceptions of and capacity for MRE and energy decentralisation (Kerr et al. 2014).

\subsection{Evaluation of global seafood campaigns}

As societal concerns regarding sustainability in seafood consumption have increased in recent years, market-based incentives and consumer behaviour have been seen as mechanisms through which positive behaviour change for the benefit of environmental conservation and management can be encouraged (Vermeir and Verbeke 2006; Barr et al. 2011; Cooke et al. 2011; Carrigan and de Pelsmacker 2014). These campaigns have generally sought to engender social changes in fish consumption through an increase in environmentally favourable behaviour (Jacquet and Pauly 2007), and have included high profile media campaigns (e.g. the UK's Fish Fight), certification schemes (e.g. Marine Stewardship Council), awareness raising and consumer guidance (e.g. Monterey Bay Aquarium's Seafood Watch (USA) and the Marine Conservation Society's Good Fish Guide (UK)). For the most part, campaigns of this nature have aimed to catalyse changes in societal behaviour to ameliorate the impacts of increased fish consumption on marine resource sustainability and biodiversity (Jacquet and Pauly 2007).

Although the Peruvian anchovy fishery has long been of commercial significance to the national economy (Alfaro-Shigueto et al. 2010; Estrella Arellano and Swartzman 2010; Christensen et al. 2014), the value of the fishery is predominantly associated with intense industrial fishing for fish meal (Alfaro-Shigueto et al. 2010; Christensen et al. 2014; PROMPERU 2015), rather than as a human food source. Fishing for fish meal, however, is of significantly less value to the wider Peruvian economy than if the fishery shifted towards human consumption (Christensen et al. 2014; Fréon et al. 2014; Cashion et al. 2017). Changing the end-user market of the anchovy fishery could add value to the existing supply chain, by providing an alternative market opportunity, while also increasing the sustainability of Peruvian fisheries. For this to be achieved, a shift in public attitudes and consumer behaviour towards anchovies is required.

There have been attempts to drive this change in behaviour. A 2014 national campaign supported by the Peruvian Government sought to encourage a change in consumption of Peruvian anchovy, moving away from the traditional view of the anchovy as a "poor 
person's fish", to one that holds the fish as a high quality, cost effective source of nutrition (IFFO 2014). However, there has been limited evaluation of the successes and failures of these campaigns and their associated activities; workshop delegates suggested that in reality little had changed in relation to anchoveta consumption. To understand how such campaigns could facilitate behaviour change, delegates identified the need to examine if, how and why certain public behaviour change campaigns have worked, while others appear to have been unsuccessful. It should be noted that the anchovy fishery is subject to a number of other drivers [e.g. government regulations limiting anchovy landings for human consumption to purse seine boats (Christensen et al. 2014)], which may have a greater influence on consumer decisions, regardless of any campaign efforts. An evaluation of global seafood campaigns would have multiple benefits across the fisheries sector. Historically, seafood campaigns, and any assessment they have undergone, have been linked to the industrial fisheries, with little emphasis on the inshore or artisanal fisheries (Cooke et al. 2011). Future campaigns in Peru could be improved by learning lessons from an evaluation of previous and existing campaigns, such as the UK's Marine Conservation Society's Good Fish Guide, Monterey Bay Aquarium's Seafood Watch in the USA, and the Peruvian Government's own anchoveta campaign. Research could identify how campaigns have been perceived by their target communities, whether they have engendered the desired behaviour change, and examine their ongoing legacy and impact on the relevant fisheries. The Peruvian anchoveta campaign provides an interesting case study for this work, as the desired behaviour change requires a shift in cultural mind set and change in perception towards human consumption of the anchovy. However, by undertaking a more global assessment of seafood campaigns, more could be learned about local and regional successes that may have the capacity to be up-scaled to a national level. Finally, if social marketing and increasing efforts of conservation marketing (Wright et al. 2015) are to be successful in achieving the positive changes to seafood consumption they seek, factors linked to general environmental citizenship (Hawthorne and Alabaster 1999), marine citizenship (McKinley and Fletcher 2010, 2012), and public attitudes will also need to be investigated.

\subsection{Overarching review of societal attitudes towards marine issues}

In recent years understanding human interactions with nature and the impact of this on perceptions, values and well-being, has been increasingly recognised as integral to marine and coastal management (Potts et al. 2016; Blasiak et al. 2015; Jefferson et al. 2015; Soma and Haggett 2015; Hawkins et al. 2016). This is evidenced by the growing interest in coupled social-ecological systems and the notion that human society is an integral component of nature; thereby requiring greater understanding of the interconnections between society and its environments (Blasiak et al. 2015).

Recent studies have continued to highlight the valuable role of public perceptions research (PPR) in understanding the diversity of societal interactions with marine and coastal environments (Blasiak et al. 2015; Jefferson et al. 2015; Hawkins et al. 2016) and the scale and scope of the potential applications of PPR is also on the rise (Jefferson et al. in prep). Understanding and value of including community values relating to marine issues in decision-making related to blue growth, remains in its infancy and is relatively fragmented when compared with terrestrial environments (Blasiak et al. 2015; Potts et al. 2016). PPR provides researchers, practitioners, policy makers and industries with a mechanism to understand human relationships with our seas though multiples lenses (Jefferson 
et al. 2015), and provides an opportunity to highlight gaps in public understanding or areas of concern in public connection with their marine environments. PPR has the potential to positively support more effective policy development, and to support better communication of marine and coastal conservation and management messages (Hawkins et al. 2016; Jefferson et al. 2015).

Embarking on a programme of PPR to evaluate public attitudes towards a range of marine issues in Peru, would have the potential to support a range of sectors, policy and decision makers and result in a more detailed understanding of public values relating to the seas. PPR can provide decision makers with an indication of the value of different types of ecosystem and resources, which can feed into the formation of management and governance strategies (Blasiak et al. 2015). This information could feed into targeted awareness raising campaigns, development of more effective protected area designations or even championing success stories linked to conservation and management success to engender greater public connection with Peruvian seas and coastal areas. Additionally, PPR could support the growing activities associated with social and conservation marketing (Wright et al. 2015), which would be of benefit to the efforts currently underway to engender a shift in consumption of the Peruvian anchoveta (see Sect. 2.5). Understanding public attitudes towards marine issues, and public connections to the seas and coasts, has the potential to support market-based initiatives encouraging positive behaviour changes for the marine and coastal environment. This understanding of the social component of marine and coastal systems could lead to increased public lobbying for renewable energy sources, and therefore increased political support for offshore renewable energy projects; it could mean a greater understanding of the value of MPAs resulting in increased support for MPA designation in Peruvian waters, or, changes to the existing fisheries activities. In addition to providing an insight into societal connections with the seas, PPR can also aid prioritisation of policy development (including marine spatial plans), and highlight public support or challenges for particular initiatives, e.g. marine renewable energy (Soma and Haggett 2015) or development of coastal tourism infrastructure (Hawkins et al. 2016). Having a thorough understanding of public views and attitudes relating to the range of blue growth opportunities available to Peru (e.g. offshore renewables, carbon storage, and coastal tourism) would ensure greater business success, and would lead to a more sustainable Peruvian blue economy.

It is the recommendation of the workshop participants that PPR should be a priority research area, as the implications of this improved understanding of social attitudes and values towards their seas and coasts would be far reaching. Initial studies would provide a baseline understanding of public viewpoints across different communities and user groups, feeding into the formation of a strong social sciences programme that could underpin Peruvian efforts to work towards long-term sustainability for the socio-economic and environmental health and well-being of the country.

\section{Concluding comments}

As global economies continue to recover from a significant period of instability and uncertainty, what has become evident is that, increasingly, we are looking towards our seas to support growth, stability, development and for an ever-growing range of resources (fisheries, energy, recreation, and tourism). The "blue economy" initiatives developing across nations continue to showcase the substantial contribution that our seas can make to social 
and economic well-being. However, it is vital that these policy approaches have the sustainability of marine and coastal environments, resources and communities at their centre.

The blue economy agenda is not without its critics. Silver et al. (2015) viewed it as a new opportunity for "blue grabbing", where common pool resources are made available for private accumulation (Benjaminsen and Bryceson 2012), and for the ascendancy of neoliberal ideals within global ocean governance. Silver et al. (2015) concerned that the application of green economy principles to the ocean may not be sufficient to halt unsustainable use and the inequity created by market-led development. This, however, creates an opportunity for Peru as it embarks on the development of a blue economy strategy. The agenda highlighted in this paper may support Peru to develop a more socially aware blue economy, one that draws on the values and needs of coastal communities, while at the same time drawing on the country's vast natural resources that lend themselves to supporting maritime industries. As outlined in the sections above, the group identified nine areas of potential research opportunity within a blue growth context - these are summarised in Table 1, alongside the recommended research requirements for each research priority.

While the list of blue economy activities discussed cannot be considered exhaustive, this paper provides a starting point for formulating a future research agenda on the blue economy of Peru. These priority areas were developed in conjunction with Peruvian researchers ensuring that they build on the best available knowledge, and that they are relevant to Peruvian marine and coastal governance, policy and industry. The authors recognise the complexities associated with effective management of marine and coastal resources, and, indeed, acknowledge that any efforts to address the research areas identified through the workshop would need to take account of the numerous land-sea interactions that can impact the quality of the marine environment (e.g. marine litter, eutrophication and other impacts associated with the pressures experienced by urban coastal areas. Peru has significant potential to develop an active and successful blue economy, with opportunities linked to the promotion of coastal tourism, harnessing ecosystem services from healthy ecosystems, establishing an MRE sector that bolsters the country's existing renewable energy objectives and diversifying the marine industry base.

This paper and the workshop that led to it are the building blocks upon which future conversations for a Peruvian blue economy can be developed. The authors and the remaining workshop attendees are already working to identity ways in which they can move this agenda forward. As a direct output from the workshop, this paper will be used by the Peruvian authors to initiate dialogue with relevant national policy makers and stakeholders, raising awareness of the potential for blue economy growth in Peru. Furthermore, the authors are working towards facilitating opportunities for knowledge exchange and best practice learning around some of the research priorities examined in this paper through collaborative research bids. Given the UK's experience in marine spatial planning, it is expected that this and other related topics (including MPA identification and designation, blue carbon, public perceptions of wider marine issues and renewable energy) could be the focus of this type of interaction.

For this to be successful, and for an active "blue economy" to be realised, there will need to be strong political will and policy driven initiatives to support the growth of a relatively under-developed, yet incredibly diverse, sector. Peru's future blue economy has the potential to provide direct and indirect employment across a range of sectors, improved marine and coastal governance that supports effective conservation and management of the underpinning marine and coastal resources, allow greater energy security through growth of the MRE market, as well as to promote a healthier, happier society. This paper provides 
Table 1 Research priorities and requirements for a future blue growth research agenda

Research priority Research requirements and recommendations

MPAs and ecosystem services Blue carbon and habitat protectio
services and carbon markets

Evolving Peruvian fisheries

Opportunities for coastal ecotourism

Marine spatial planning

Marine renewables

Evaluation of global seafood campaigns

Overarching review of societal attitudes towards marine issues
Baselines data collection on marine and coastal ES

Detailed review of the benefits and services provided by different marine and coastal systems

Application of the ES framework to assess benefits of MPAs

Map and evaluate blue carbon stores in Peru Establish a Peruvian Blue Carbon strategy

Evaluation of Peruvian fishery supply chains

Scenario modelling to assess impacts of management interventions and change

Examination of public attitudes towards fisheries

Mapping of coastal ecosystems and linked social-cultural systems

Evaluation of feasibility and social acceptability of coastal (eco) tourism

Assess environmental impact and mitigation measures

Sustainable regeneration of the guano industry Spatial mapping of guano-harvesting activities

Examination of local, regional and global market opportunities

Evaluation of existing regulations and management

Mapping of all marine activities, drivers, pressures and uses

Identification of potential community engagement approaches

Assessment of integration between marine and terrestrial plans

Investigate potential for combined MRE arrays

Support for R\&D in engineering and design

Evaluation of capacity and feasibility for an enhanced MRE sector

Assess the effectiveness and impact of global seafood campaigns

Investigate the role of social and conservation marketing in positive behaviour change

Develop a baseline study of public perceptions towards marine issues

Assess public connections with the seas

a basis for policy and decision makers working towards a blue economy strategy for Peru, an effort that will demand investment and requite strong leadership.

Acknowledgements The authors of this paper would like to acknowledge the British Council for providing the funding to support the Green Economy workshop, held in Lima, Peru, in March 2016. Additionally, the authors would like to thank the University of Aberdeen, the Universidad Científica Del Sur and the Pontifical Catholic University of Peru for co-organising the workshop. Dr Emma McKinley also acknowledges the financial support provided by the Welsh Government and Higher Education Funding Council for Wales through the Ser Cymru National Research Network for Low Carbon, Energy and Environment.

Open Access This article is distributed under the terms of the Creative Commons Attribution 4.0 International License (http://creativecommons.org/licenses/by/4.0/), which permits unrestricted use, distribution, 
and reproduction in any medium, provided you give appropriate credit to the original author(s) and the source, provide a link to the Creative Commons license, and indicate if changes were made.

\section{References}

Acott, T. G., La Trobe, H. L., \& Howard, S. H. (1998). An evaluation of deep ecotourism and shallow ecotourism. Journal of Sustainable Tourism, 6, 238-253.

Agardy, T., di Sciara, G. N., \& Christie, P. (2011). Mind the gap: Addressing the shortcomings of marine protected areas through large scale marine spatial planning. Marine Policy, 35, 226-232.

Ahmed, N., \& Glaser, M. (2016). Coastal aquaculture, mangrove deforestation and blue carbon emissions: Is REDD + a solution? Marine Policy, 66, 58-66.

Alfaro-Shigueto, J., Mangel, J. C., Pajuelo, M., Dutton, P. H., Seminoff, J. A., \& Godley, B. J. (2010). Where small can have a large impact: Structure and characterization of small-scale fisheries in Peru. Fisheries Research, 106, 8-17.

Alongi, D. M., Murdiyarso, D., Fourqurean, J. W., Kauffman, J. B., Hutahaean, A., Crooks, S., et al. (2016). Indonesia's blue carbon: a globally significant and vulnerable sink for seagrass and mangrove carbon. Wetlands Ecology and Management, 24, 3-13.

Anon. (2014). Blue economy concept paper, United Nations Sustainable Development Knowledge Platform, Department of Social and Economic Affairs. https://sustainabledevelopment.un.org/index .php? page $=$ view $\&$ type $=111 \& n r=2978 \&$ menu $=35$. Accessed on 15/03/2018.

Apaza, M., \& Figari, A. (1999). Mortandad de aves marinas durente El Niño 1997-98 en el litoral sur de San Juan de Marcona, Ica-Perú. En: El Niño 1997-98 y su impacto sobre los ecosistemas marino y terrestre. Revista peruana de Biología., Volumen extraordinario, 110-117.

Apergis, N., \& Payne, J. E. (2010). Energy consumption and growth in South America: Evidence from a panel error correction model. Energy Economics, 32, 1421-1426.

Aponte, H., \& Cano, A. (2013). Estudio Florístico Comparativo De Seis Humedales De La Costa De Lima (Perú): Actualización Y Nuevos Retos Para Su Conservación. Revista Latinoamericana De Conservación, 3, 15-27.

Bakun, A., \& Weeks, S. J. (2008). The marine ecosystem off Peru: What are the secrets of its fishery productivity and what might its future hold? Progress in Oceanography, 79, 290-299.

Barr, S., Gilg, A., \& Shaw, G. (2011). "Helping people make better choices": Exploring the behaviour change agenda for environmental sustainability. Applied Geography, 31, 712-720.

BCRP. (2016). Banco Central de Reserva del Perú. Cuadros Anuales Históricos.

Benjaminsen, T. A., \& Bryceson, I. (2012). Conservation, green/blue grabbing and accumulation by dispossession in Tanzania. Journal of Peasant Studies, 39, 335-355.

Blasiak, R., Yagi, N., Kurokura, H., Ichikawa, K., Wakita, K., \& Mori, A. (2015). Marine ecosystem services: Perceptions of indispensability and pathways to engaging citizens in their sustainable use. Marine Policy, 61, 155-163.

Borthwick, A. G. L. (2016). Marine renewable energy seascape. Engineering, 2, 69-78.

Bury, J. (2008). New geographies of tourism in Peru: Nature-based tourism and conservation in the Cordillera Huayhuash. Tourism Geographies, 10, 312-333.

Carrigan, M., \& de Pelsmacker, P. (2014). Will ethical consumers sustain their values in the global credit crunch? International Marketing Review, 26, 674-687.

Cashion, T., Le Manach, F., Zeller, D., \& Pauly, D. (2017). Most fish destined for fishmeal production are food-grade fish. Fish and Fisheries, 18(5) 837-844.

Cavanagh, R. D., Broszeit, S., Pillin, G. M., Grant, S. M., Murphy, E. J., \& Austen, M. C. (2016). Valuing biodiversity and ecosystem services: A useful way to manage and conserve marine resources? Procedings of Royal Society B, 283, 1-8.

Ceballos-Lascurain, H. (1993). Overview on ecotourism around the world: IUCN's ecotourism program. In Proceedings of the 1993 world congress on adventure travel and eco-tourism, The Adventure Travel Society, Englewood.

Chae, D., Wattage, P., \& Pascoe, S. (2012). Recreational benefits from a marine protected area: A travel cost analysis of Lundy. Tourism Management, 33, 971-977.

Christensen, V., De la Puente, S., Sueiro, J. C., Steenbeek, J., \& Majluf, P. (2014). Valuing seafood: The Peruvian fisheries sector. Marine Policy, 44, 302-311. 
Cooke, S. J., Murchie, K. J., \& Danylchuk, A. J. (2011). Sustainable "seafood" ecolabeling and awareness initiatives in the context of inland fisheries: Increasing food security and protecting ecosystems. BioScience, 61, 911-918.

Copping, A., Battey, H., Brown-Saracino, J., Massaua, M., \& Smith, C. (2014). An international assessment of the environmental effects of marine energy development. Ocean and Coastal Management, 99, 3-13.

Crawford, R. J. M., \& Jahncke, J. (1999). Comparison of trends in abundance of guano-producing seabirds in Peru and southern Africa. South African Journal of Marine Science, 21, 145-156.

Creaney, R., \& Niewiadomski, P. (2016). Tourism and sustainable development on the Isle of Eigg, Scotland. Scottish Geographical Journal, 132, 210-233.

DEVEX. (2015). Tender: Analysis of the existing laws and proposals for future laws-coastal and marine spatial planning (CMSP) in Peru.

Donlan, J., Gelcich, S., \& Sfeir, A. (2014). Advanced conservation strategies. A marine conservation assessment in Peru (pp. 1-78). Los Altos: The David and Lucile Packard Foundation \& Fondation Ensemble.

Douvere, F. (2008). The importance of marine spatial planning in advancing ecosystem-based sea use management. Marine Policy, 32, 762-771.

Duffy, D. C. (1994). The guano islands of Peru: The once and future management of a renewable resource. Seabirds on Islands, Threats, Case Studies and Action Plans, 1, 68-76.

Duffy, R. (2015). Nature-based tourism and neoliberalism: Concealing contradictions. Tourism Geographies, 17, 529-543.

ECLAC, and OECD. (2016). Environmental performance reviews: Peru 2016 highlights and recommendations.

Ehler, C. (2008). Conclusions: Benefits, lessons learned, and future challenges of marine spatial planning. Marine Policy, 32, 840-843.

Estrella Arellano, C., \& Swartzman, G. (2010). The Peruvian artisanal fishery: Changes in patterns and distribution over time. Fisheries Research, 101, 133-145.

European Commission. (2012). Blue growth: Opportunities for marine and maritime sustainable growth. Communication from the Commission to the European Parliament, The Council, The European Economic and Social Committee and the Committee of the Regions.

Fairhead, J., Leach, M., \& Scoones, I. (2012). Green Grabbing: a new appropriation of nature? The Journal of Peasant Studies, 39, 237-261.

FAO. (2010). National Fisheries Sector Overview-Perú. http://www.fao.org/fishery/docs/DOCUMENT/ fcp/en/FI_CP_PE.pdf. Accessed on 15/03/2018.

FAO. (2012). Estado de las áreas marinas y costeras protegidas en América Latina. Elaborado por Aylem Hernández Avila. REDPARQUES Cuba. Santiago de Chile.

FAO. (2013). Achieving blue growth through implementation of the code of conduct for responsible fisheries. http://www.fao.org/fileadmin/user_upload/newsroom/docs/BlueGrowth_LR.pdf. Accessed on $15 / 03 / 2018$.

FAO. (2016). The state of the world fisheries and aquaculture 2016.

Fréon, P., Sueiro, J. C., Iriarte, F., Miro Evar, O. F., Landa, Y., Mittaine, J. F., et al. (2014). Harvesting for food versus feed: A review of Peruvian fisheries in a global context. Reviews in Fish Biology and Fisheries, 24, 381-398.

Gopnik, M., Fieseler, C., Cantral, L., McClellan, K., Pendleton, L., \& Crowder, L. (2012). Coming to the table: Early stakeholder engagement in marine spatial planning. Marine Policy, 36, 1139-1149.

Grimsditch, G., Alder, J., Nakamura, T., Kenchington, R., \& Tamelander, J. (2013). The blue carbon special edition-Introduction and overview. Ocean and Coastal Management, 83, 1-4.

Guezel, R., \& Wickel, J. (2015). Riqueza Ecológica Y Áreas Vulnerables de la Bahia de Paracas. Saber y Hacer, 2(1).

Hannesson, R. (2013). Strictly for the birds? On ecosystem services of forage fish. Marine Policy, 38, 109-115.

Hawkins, J. P., O’Leary, B. C., Bassett, N., Peters, H., Rakowski, S., Reeve, G., et al. (2016). Public awareness and attitudes towards marine protection in the United Kingdom. Marine Pollution Bulletin, 111, 231-236.

Hawthorne, M., \& Alabaster, T. (1999). Citizen 2000: development of a model of environmental citizenship. Global Environmental Change, 9, 25-43.

Hooker, Y. (2011). Criterios de Zonificación para Áreas Marinas Protegidas del Perú. Unidad Marino Costera, Servicio Nacional de Áreas Naturales Protegidas por el Estado (SERNANP - MINAN), Perú. Rev. areas mar. prot., Perú $N^{\circ} 1$. 
Howard, J., Hoyt, S., Isensee, K., Pidgeon, E., \& Telszewski, M. (2014). Coastal blue carbon. Conservation International, 36, 180.

IFFO. (2014). Campaign launched to promote anchovy consumption in Peru. http://www.iffo.net/node/527. Accessed on 15/03/2018.

IOC-UNESCO. (2018). Balancing sustainable use and conservation through marine spatial planning. http:// msp.ioc-unesco.org/ Accessed on 26/02/2018.

Ipenza Peralta, C. (2010). El Convenio sobre la Diversidad Biológica en el Perú - Análisis de su aplicación y avances en el Perú. MINAM, Lima, Perú.

IUCN. (2013). A bird droppings biodiversity paradise-The guano islands and capes national reserve system, Peru.

Jacquet, J. L., \& Pauly, D. (2007). The rise of seafood awareness campaigns in an era of collapsing fisheries. Marine Policy, 31, 308-313.

Jahncke, J., Jahncke, J., Checkley, D. M. J., Checkley, D. M. J., Jr, H., \& Hunt, G. L., Jr. (2004). Trends in carbon flux to seabirds in the Peruvian upwelling system: Effects of wind and fisheries on population regulation. Fisheries Oceanography, 13, 208-223.

Jefferson, R., McKinley, E., Capstick, S., Fletcher, S., Griffin, H., \& Milanese, M. (2015). Understanding audiences: Making public perceptions research matter to marine conservation. Ocean and Coastal Management, 115, 61-70.

Kerr, S., Watts, L., Colton, J., Conway, F., Hull, A., Johnson, K., et al. (2014). Establishing an agenda for social studies research in marine renewable energy. Energy Policy, 67, 694-702.

Leeney, R. H., Greaves, D., Conley, D., \& O’Hagan, A. M. (2014). Environmental impact assessments for wave energy developments-learning from existing activities and informing future research priorities. Ocean and Coastal Management, 99, 14-22.

Leon, B., \& Young, K. R. (1996). Aquatic plants of Peru: Diversity, distribution and conservation. Biodiversity and Conservation, 5, 1169-1190.

Llorca-Rodríguez, C., Casas-Jurado, A., \& García-Fernandez, R. (2014). Regional polarization of contribution of tourism to economic growth in Peru: Alternative solutions. Tourism Economics, 22, 397-415.

López, M., Veigas, M., \& Iglesias, G. (2015). On the wave energy resource of Peru. Energy Conversion and Management, 90, 34-40.

Luisetti, T., Jackson, E. L., \& Turner, R. K. (2013). Valuing the European “coastal blue carbon” storage benefit. Marine Pollution Bulletin, 71, 101-106.

Maes, F. (2008). The international legal framework for marine spatial planning. Marine Policy, 32, 797-810.

Maguire, B., Potts, J., \& Fletcher, S. (2011). Who, when, and how? Marine planning stakeholder involvement preferences-A case study of the Solent, United Kingdom. Marine Pollution Bulletin, 62, 2288-2292.

McKinley, E., \& Fletcher, S. (2010). Individual responsibility for the oceans? An evaluation of marine citizenship by UK marine practitioners. Ocean and Coastal Management, 53, 379-384.

McKinley, E., \& Fletcher, S. (2012). Improving marine environmental health through marine citizenship: A call for debate. Marine Policy, 36, 839-843.

MINAM. (2016). Áreas Naturales Protegidas del Perú.

Ministerio del Ambiente. (2009). Politica Nacional del Ambiente (Version Ingles).

Mowforth, M., \& Munt, I. (2009). Tourism and sustainability: Development, globalisation and new tourism in the third world (3rd ed.). London: Routledge.

Nellemann, C., E. Corcoran, C. Duarte, L. Valdes, C. DeYoung, L. Fonseca, G. Grimsditch, and (eds). (2009). Blue carbon. A rapid response assessment. united nations environment programme, GRIDArendal. https://cld.bz/bookdata/WK8FNPt/basic-html/index.html\#1. Accessed on 15/03/2018.

Norton Rose Fulbright. (2017). Renewable Energy in Latin America. http://www.nortonrosefulbright. com/files/renewable-energy-in-latin-america-134675.pdf. Accessed on 15/03/2018.

OECD. (2015). Green growth in fisheries and aquaculture. http://www.oecd.org/environment/green -growth-in-fisheriesand-aquaculture-9789264232143-en.htm. Accessed on 15/03/2018.

OECD. (2016). OECD Territorial Reviews: Peru 2016. http://www.oecd.org/countries/peru/oecd-terri torial-reviews-peru-2016-9789264262904-en.htm Accessed 16/05/2017.

Palomino Contreras \& Cabrera Carranza (2007). Estimación del servicio ambiental de captura del CO2 en la flora de los humedales de Puerto Viejo. Revista del Instituto de Investigaciones FIGMMG. Vol. 10, № 20, 49-59 (2007)

Pelc, R., \& Fujita, R. M. (2002). Renewable energy from the ocean. Marine Policy, 26, 471-479. 
Pendleton, L., Donato, D. C., Murray, B. C., Crooks, S., Jenkins, W. A., Sifleet, S., et al. (2012). Estimating global "blue carbon" emissions from conversion and degradation of vegetated coastal ecosystems. PLOS ONE, 7, 1-7.

Pomeroy, R., \& Douvere, F. (2008). The engagement of stakeholders in the marine spatial planning process. Marine Policy, 32, 816-822.

Potts, T. (2016). The blue economy: (R)evolution or treading water? Presented in the session: "A blue revolution?: Harnessing 'blue economy' opportunities in the Pacific and East Asia". In Ocean issues for the Pacific and East Asia conference. November 2016, Australian Nation.

Potts, T., Burdon, D., Jackson, E., Atkins, J., Saunders, J., Hastings, E., et al. (2014). Do marine protected areas deliver flows of ecosystem services to support human welfare? Marine Policy, 44, 139-148.

Potts, T., Pita, C., O’Higgins, T., \& Mee, L. (2016). Who cares? European attitudes towards marine and coastal environments. Marine Policy, 72, 59-66.

PROMPERU. (2015). Departamento de Productos Pesqueros de la Sub Dirección de Promoción Internacional de la Oferta Exportable. Informe anual 2016 Desenvolvimiento del Comercio Exterior Pesquero. www.siicex.gob.pe/pesca/. Accessed on 15/03/2018.

Pronaturaleza. (2010). Documento base para la elaboración de una Estrategia De Conservación de Los Humedales de la Costa Peruana.

RAMSAR. (2008). Manglares de San Pedro de Vice.

Rebours, C., Marinho-Soriano, E., Zertuche-González, J. A., Hayashi, L., Vásquez, J. A., Kradolfer, P., et al. (2014). Seaweeds: An opportunity for wealth and sustainable livelihood for coastal communities. Journal of Applied Phycology, 26, 1939-1951.

REVE. (2016). Wind energy and electric vehicle review.

SERNANP. (2009). Servicio Nacional de Áreas Naturales Protegidas por el Estado. Plan Director de las Áreas Naturales Protegidad (Estrategia Nacional) 2009-2018.

Sevilla, N. P. M., \& Le Bail, M. (2017). Latin American and caribbean regional perspective on ecosystem based management (EBM) of large marine ecosystems goods and services. Environmental Development. Environmental Development, 22(2017), 9-17.

Silver, J. J., Gray, N. J., Campbell, L. M., Fairbanks, L. W., \& Gruby, R. L. (2015). Blue economy and competing discourses in international oceans governance. The Journal of Environment \& Development, 24, 135-160.

Smith, H. D., Maes, F., Stojanovic, T. A., \& Ballinger, R. C. (2011). The integration of land and marine spatial planning. Journal of Coastal Conservation, 15, 291-303.

Soma, K., \& Haggett, C. (2015). Enhancing social acceptance in marine governance in Europe. Ocean and Coastal Management, 117, 61-69.

Tarazona, J., Gutiérrez, D., Paredes, C., \& Indacochea, A. (2003). Overview and challenges of marine biodiversity research in Peru. Gayana, 67, 206-231.

Tidal Energy Today. (2015). Atmocean deploys its wave energy system off Peru.

Turner, J., \& Essex, S. (2016). Integrated terrestrial and marine planning in England's coastal inter-tidal zone: Assessing the operational effectiveness of the Coastal Concordat. Marine Policy, 72, 166-175.

UNEP. (2011). Towards a green economy: Pathways to sustainable development and poverty eradication. A synthesis for policy makers.

UNEP. (2012). Green economy in a blue world. A synthesis report.

United Nations Economic Commission for Africa. (2016). Africa's Blue Economy: A policy handbook. http://www.uneca.org/sites/default/files/PublicationFiles/blueeco-policy-handbook_en.pdf. Accessed on $15 / 03 / 2018$.

Vermeir, I., \& Verbeke, W. (2006). Sustainable food consumption: Exploring the consumer "attitudeBehavioral intention" gap. Journal of Agricultural and Environmental Ethics, 19, 169-194.

Walker, G., \& Devine-Wright, P. (2008). Community renewable energy: What should it mean? Energy Policy, 36, 497-500.

Woodland, M., \& Acott, T. G. (2007). Sustainability and local tourism branding in England's South Downs. Journal of Sustainable Tourism., 15(6), 715-734.

World Bank. (n.d.). International tourism, number of arrivals. World Bank data.

World Bank. (2006). Republic of Peru environmental sustainability : A key to poverty reduction in Peru. Page Country Environmental Analysis.

Wright, A. J., Veríssimo, D., Pilfold, K., Parsons, E. C. M., Ventre, K., Cousins, J., et al. (2015). Competitive outreach in the 21st century: Why we need conservation marketing. Ocean and Coastal Management, 115, 41-48.

Wüstenhagen, R., Wolsink, M., \& Bürer, M. J. (2007). Social acceptance of renewable energy innovation: An introduction to the concept. Energy Policy, 35, 2683-2691. 
Young, J., \& Lankester, K. (2013). Catch shares in action: Peruvian Anchoveta Northern-Central Stock Individual vessel quota program. Environmental Defense Fund. http://www.iffo.net/node/527. Accessed on $15 / 03 / 2018$. 